Dr. Dotaras thought that as insanity made the mental condition practically dead to the duties and obligations of the married state it might be a justifiable plea for divorce.

Dr. SUTHRRLAND mentioned cases which had come within his experience where the maintenance of the contract inflicted great hardships.

Dr. STEWART believed that the relief sought should be confined to incurable cases.

On the discussion closing, the subject was put to the vote, and the questions the section was asked to decide were:-

1st. Is insanity at the time of marriage a sufficient plea for divorce?-This was unanimously agreed to.

2nd. Is a fraudulent marriage (that is, where the knowledge of the insanity of one is kept from the other contracting party) a sufficient plea for divorce PThis was also agreed to unanimously.

3rd. Is incurable insanity, after a specified time of skilled supervision, a sufficient plea for divorce ?-Ayes, 17; noes, 13.

Dr. W $A R N E R$ gave a report upon exceptional children, and Dr. PoPR, of Leicester, read a note on the establishment of a special class for foeble-minded children by the Sohool Board of Leicester.

Mr. ABEL, Clerk of the Nottingham School Board, also spoke as to the value of Dr. Warner's researches in this connection, and a resolution confirmatory of Dr. Warner's report was passed.

Papers were also read by Dr. Lloyd Tuckey on "The Value of Hypnotism in Chronic Alcoholism;" and by Dr. Robertson on "The Use of Hypnotism among the Insane." Drs. Hack Tuke, Draper, Stewart, and Bedford Pierce joined in the discussion.

\title{
THE INTERNATIONAL CONGRESS OF EXPERIMENTAL PSYCHOLOGY.
}

The subject of experimental psychology seems to be attracting an everincreasing number of scientists, and the Congress beld on the first four days of Angust last will be remembered, not only for the many valuable papers read and the discussions connected with them, but also from the large number of eminent men from other countries who were present, and who contribnted largely to the business of the meetings. In fact, so numerous and varied were the communications that the executive found it necessary, in order to get through the business, to divide the work of the Congress into two sections. Each morning there was a general meeting of the whole Congress, and in the afternoons the two sections sat.

Professor Sidgwick, who presided, was supported by the following vice. presidents :-Professor A. Bain, Professor Baldwin, Professor Bernheim, Professor Ebinghaus, Professor Ferrier, Professor Hitzig, Professor Liégeois, Professor Preyer, Professor Delbøuf, Professor Richet, and Professor Sohäfer. The honorary secretaries were Mr. F. W. H. Myers and Mr. James Sully, and to their energy and skill in organizing the work of the Congress the sucoess achieved was mainly due.

The meetings were held in University College, where ample accommodation was afforded for the large number of members present. The Congress numbers about 270 members, and a large proportion were present each day.

In the space at our command we can bat give the list of the papers read; to enter into a description of them would be impossible. The greatest interest seemed to be centred in the question of Hypnotism and cognate questions, 
whioh were discussed in Section B, while in Section A Neurology and Psychophysics were the topios for consideration.

The proceedings commenoed with an opening addrese by the President, who in cordial terms welcomed the numerons members from across the Atlantio and from the Continent. There were many ladies present each day, and several took an active part in the work of the session. Mrs. Sidgwick's paper on "Thought Transference" was, indeed, one of the most interesting contributions to the Congress, whether convincing or not.

The following is a list of the papers set down for reading on Monday, Angust 1st:-

Professor Bain, "The Respective Spheres and the Matual Aids of Introspection and Experiment in Psychology;" Professor Baldwin, "Suggestion and Will;" Professor Ribot, "General Ideas ;" Professor Richet, "The Future of Psychology ; " Professor Janet, "Loss of Volitional Power; " Dr. Newbold, "The Characteristics and Conditions of the Simplest Forms of Belief ;" Professor Lombroso, "The Sensibility of Women : Normal, Insane, and Criminal."

Tursday, AUgust 2ND.

Professor Henschen, "The Visual Centre in the Cortex of Calcarine Fissure;" Professor Horsley, "The Degree of Localization of Movements and Correlative Sensations;" Professor Schäfer, "The Anatomical and Physiological Relations of the Frontal Lobes;" Dr. Waller, "On the Funotional Attributes of the Cerebral Cortex;" Professor Bernheim, "The Psychical Character of Hysterical Amblyopia;" Dr. Van Eeden, "Principles of Psycho-Therapentics ;" Professor Liégeois, "The Female Poisoner of AinnFezza ;" Dr. Liébault "A Case of Suicidal Monomania Cured by Suggestion ;" Professor Preyer, "The Origin of Numbers ;" Professor Ebbinghaus, "Theory of Colour Perception; " Mrs. C. L. Franklin, "Colour Perception;" Professor Lloyd Morgan, "The Limits of Animal Intelligence;" Professor Lange, "A Law of Perception."

WRDNESDAT, AUGUST 3RD.

Dr. Verriest, "The Physiological Basis of Rhythmic Speech ; " Dr. Mendelssohn, "Investigations into the Parallel Law of Fechner;" Professor Heymans, "Inhibition of Presentations ; " M. Binet, "The Psychology of Insects;" Professor Delbøuf, "The Appreciation of Time by Somnambulists ; " Professor Hitzig, "Attacks of Sleep and Hypnotic Suggestion ;" Mr. Myers, "The Esperimental Induction of Hallucinations;" Professor Münsterberg, "The Psycho-Physical Basis of the Feelings; " the President, Professor W. James, and M. Marillier, "Reports of the Census of Hallucinations;" Professor Beannis, "Psychological Questioning."

Thursday, August 4tri.

Dr. E. B. Titchener, "Binocular Effects of Monocular Stimulation;" Dr. Donaldson, "Laura Bridgman ;" Professor Lehmann, "Experimental Inquiry into the Relation of Respiration to Attention ;" Dr. Goldscheider, "Investigations into the Muscular Sense of the Blind ;" Dr. Berillon, "The Application of Hypnotic Suggestion to Edncation;" Mrs. Sidgwiok, "Experiments in Thougbt Transference;" Dr. Lightner-Witmer, "The Direct and Associative Factors in Judgments of Atsthetio Proposition;" Dr. Wallasohek, "Natural Selection and Music;" Professor von Tsohisoh, "Relation of Reaction-Time to Breadth of Perception."

At the conclusion of the papers on the last two days, Dr. Bramwell gave demonstrations of the phenomens of Hypnotism. These demonstrations attracted a crowded andience, and much interest was shown in the effects of posthypnotio suggestion.

XXXVIII. 